\title{
Diversity of Food-Borne Pathogens Isolated from Raw Meat Sample
}

\author{
Taqdees Malik*, Nazish Mumtaz Ali and Aziz Fatima \\ Department of Microbiology, Jinnah University for Women, Pakistan
}

*Corresponding author: Taqdees Malik, Department of Microbiology, Jinnah University for Women, ST-1 Nazimabad, Karachi -7500, Pakistan

\begin{abstract}
Foodborne diseases are considered to be the wide-spread health problem in most parts of the world especially in developing countries. The aim of the study evaluates the frequency of microbial contamination of raw meat that is often contaminated with foodborne pathogens. The perishable nature of nutritious meat is one of the potential sources of pathogens as well as an excellent vehicle for transmitting foodborne disease in human beings. In this study, Six $(n=6)$ samples of meat such as beef, mutton, lamb, chicken, fish, camel meat were collected from common retail shop of Karachi and analyzed for the prevalence of pathogenic microorganism by using standard plate methods to purify it on specific agar and to perform biochemical testing for identification and isolation of bacterial species. In our study, it was found that 33\% isolates of $S$. typhi and S. aureus were found whereas $17 \%$ isolates of E. coli and Klebsiella pneumoniae were detected from various meat samples. It is therefore expedient that great care should be taken during handling and good hygiene practices should be followed to reduce the microbial load to a harmless level.
\end{abstract}

Keywords: Food; Disease; Organisms; Meat sample

\section{Introduction}

Meat has long been known for its enrichment composition containing a rich source of protein, carbohydrate, vitamins, and fats. Most people rely on meat due to the presence of this entire rich nutrient that is required for the human body. Meat including beef, mutton, poultry, fish, lamb, and camel meat [1].

\section{Nutritional composition of beef and mutton and their} role in the human immune system

Meat is one of the most edible and delicious food in the world that play a role in human metabolic functions. Beef and mutton meat contain a large amount of protein and Vitamin (B12, B3 (Niacin), B6), Iron, Zinc, Selenium, and minerals. This could be beneficial to the body for the building of body tissues and help in the repair mechanism. It also helps in the production of antibodies to build up immune system [2].

\section{Composition of fish with the supplement of Omega 3 and} their role in the human body

Proteins are the second major part of a fish constituent. Two essential amino acids called lysine and methionine are generally found in high concentrations in fish. Fish meat is also a valuable source of minerals such as sodium, potassium, magnesium, phosphorous, iron, and omega 3 fatty acids that can help in reproduction and brain development. Fish also has non-protein nitrogen (NPN) fraction which is water-soluble. The constituents of the NPN fraction play a major role in the quality of fish [3]. Raw fish is often contaminated with foodborne pathogens. It provides a perfect medium for the growth of the microbial pathogens such as Salmonella, Escherichia coli, Shigella sonnie and Listeria monocytogenes. They have been found in raw fish through washing water or may be from contact surfaces [4].

\section{Composition of lamb meat and their function in the human body}

Lamb meat is an excellent source of Vitamins B6, B12, protein, zinc phosphorous, selenium, folate, and choline that act as an antioxidant that prevents reactive oxygen species in the body. They also reduced the level of unwanted accumulation of homocysteine in the body. High blood levels of homocysteine responsible for causing cardiovascular disease. Another property 
of grass feed lamb meat contains Conjugated linoleic acid (CLA) that helps in reducing inflammation and body extra fat. The combination of both can reduce the risk of heart diseases [5]. Lamb meat can be contaminated with a variety of microorganisms such as Staphylococci, Corynebacterium, Streptococci, Micrococcus, Salmonella, Escherichia coli, coliform and Yeast [6].

\section{Composition of fatless camel meat used for medicinal purpose}

The demand for camel meat is mainly due to the health benefit purposes. It is a source of high-quality meat due to the presence of unsaturated fatty acids like linoleic acid which prevents from tumor or cancerous diseases. It also contains less fat content which is recommended for weight loss and prevent from heart diseases and atherosclerosis. It also reduces cholesterol level in the blood $[7,8]$.

\section{Composition of chicken and spread of microorganism in poultry meat}

Chicken meat is one of the most consumed food in Pakistan. It is nutritious with rich protein content. All vitamin B are present in chicken meat, including B1, B2, B3, B5, B6, B12, folate, biotin, choline, selenium, zinc, copper, and omega 3. Recent research has proved that intake of chicken meat can reduce the risk of colorectal cancer. It contains fiber that can lower blood cholesterol and blood LDL-cholesterol [9]. Poultry meat is contaminated with a variety of microorganisms, including those capable of spoiling at freezing temperatures. Raw chicken meat is contaminated with certain foodborne pathogens such as Campylobacter jejuni, Salmonella enteritis, Staph aureus, Listeria monocytogenes. Others may also be present which includes the most recently reported Arcobacter and Helicobacter spp and occasionally, verotoxigenic Escherichia coli [10].

\section{Spoilage of Meat}

The perishable nature of meat is highly sensitive to spoilage by contact with different microorganisms through exogenous and endogenous sources. Out of which, the intestinal tract of animal is the main source of microorganism. Organism that may infect a living animal causing endogenous diseases may also spoil the meat. Consumption of this meat from an infected animal can cause diseases in human. Three sources of exogenous contamination are by slaughtering, handling, and processing. Due to these biochemical changes that allow microorganisms to grow in meat and carry the greater chances of contamination [11]. Microbial spoilage of food is an area of global concern, causing serious foodborne intoxications and resulting in high economic losses for the food-producing sector.

The predominant bacteria associated with spoilage of meat are Carnobacterium spp., Enterobacteriaceae, Lactobacillus spp., Leuconostoc spp., Pseudomonas spp. and Shewanella putrefacients [12]. The poikilothermic nature of fresh fish meat that allows a wide variety of bacteria to grow and spoiled the fish which includes Gram- negative, rod-shaped bacteria which belong to the genera Pseudomonas, Moraxella, Acinetobacter, Shewanella, Flavobacterium, Aeroemonadaceae, and Vibrionaceae, and Grampositive bacteria such as Bacillus, Micrococcus, Clostridium, Lactobacillus, and Corynebacterium $[13,14]$.

\section{Mechanism of rigor mortis occurring in meat}

Rigor mortis is a physiological change that occurs after the death of an animal in which the hardening of skeletal muscles becomes maintained for a certain period approximately within 12 to $24 \mathrm{hrs}$. then gradually flexible after 24 hours. Normally glycogen present in the muscles of the animal. When the animal is slaughtered in the excited state, its glycogen converts into lactic acid in bulk amount. Suddenly the change in $\mathrm{pH}$ is occurred which turns into acidic so it allows acidophilic bacteria to grow which can spoil the meat easily. The process is known as rigor mortis occurring in meat [15]. Greater chances of bacterial contamination during slaughtering and then cutting by using tools such as knives, wooden board, weighing scale and meat mincer. Or it may the meat handler who is shedding microbes and can act as a carrier.

\section{Presence of foodborne pathogens in meat through contact surfaces and processing}

The perishable nature of meat provides a substrate to support the growth of microorganisms in meat. Meat contains a wide range of pathogenic microorganism that is obtained either from contaminated surfaces or during processing. Most of these bacteria can produce biofilms that protect them from external harm and enable them to adhere strongly to contact surfaces. The greater chances of bacterial pathogens during meat-processing and their equipment so the surfaces and processing both may contribute to the contamination of meat [16].

\section{Bacterial Foodborne Diseases}

Foodborne diseases are a major cause of death in developing countries by representing an important public health problem worldwide. It is assumed that foodborne and waterborne diarrheal diseases kill more than 2.2 million people each year. Foodborne diseases resulting from the ingestion of bacteria, toxins, and cells

produced by microorganisms present in food. Toxins may not alter the appearance, odor, or flavor of food but may cause food poisoning. Common kinds of bacteria that produce toxins include Staphylococcus aureus and Clostridium botulinum. The intensity of the signs and symptoms may vary with the amount of contaminated food ingested and susceptibility of the individuals to the toxin. Foodborne microorganisms can cause severe illnesses to humans which may also lead to the drug resistance $[17,18]$.

Approximately $69 \%$ of gram-negative bacteria are known to cause bacterial foodborne diseases. Several researchers have reported that the meat samples contaminated with a higher load of Klebsiella pneumoniae, Enterobacter spp, Pseudomonas aeruginosa, 
E. coli, Salmonella sp, Serratia marcescens, Proteus Vulgaris, Staphylococcus aureus and Bacillus sp. On the other hand, foodborne pathogens can disseminate from contaminated meat to the surfaces and can spread infections in the community [19-23].

\section{Antibiotic Resistivity}

Some bacteria have developed resistance against antibiotics that are not killed or controlled by antibiotics even they can multiply in the presence of these drugs. It could be more difficult to treat people if they became ill with the antibiotic-resistant strains such as the most recently reported resistance is carbapenem-resistant Enterobacteriaceae (CRE). These strains have developed resistance against carbapenem drug e.g. Klebsiella. Staph. aureus is found to be resistant against multi drugs and falls in the group of Methicillinresistant Staphylococcus aureus (MRSA), Salmonella typhi is found resistant against chloramphenicol, ampicillin, tetracycline, and trimethoprim. They are responsible for a well-known public health problem [24].

\section{Materials and Methods}

\section{Sample collection}

A total of Six $(n=6)$ samples of raw meat were collected in a sterile container which includes minced chicken, beef, mutton, lamb, camel, and fish. 1 gram of each minced meat samples was weighed and transferred into a tube containing $9 \mathrm{ml}$ of selenite broth for enrichment. Then it was incubated at $37^{\circ} \mathrm{C}$ for 24 hours. After incubation, streaking was done on nutrient agar plate. And the plates were incubated at $37^{\circ} \mathrm{C}$ for 24 hours to the study was carried out to determine the microbial load among different raw meat available in common retail shops of Karachi, Pakistan. This study is designed to characterize the foodborne pathogens, which include $S$. aureus, E. coli, Salmonella, and Klebsiella isolated from raw meat samples and to determine the susceptibility pattern of isolated bacterial strains against the frequently prescribed antibiotics. These isolated bacterial strains are known as foodborne pathogens resulting in food intoxication. This research is necessary to the public which will create awareness among the consumers to prevent foodborne illnesses. Observe the colonial characteristics on nutrient agar and to perform gram staining and further identification tests to identify the isolates.

\section{Antibiotic Susceptibility Testing}

Antibiotic susceptibility testing is performed by using KirbyBauer disc diffusion method in which loop full culture of the identified isolate was streaked on MHA plate and antibiotics are dispensed on it. Zone of inhibition was observed after incubation of 24 hours at $37^{\circ} \mathrm{C}$ as per CLSI guidelines (Table 1).

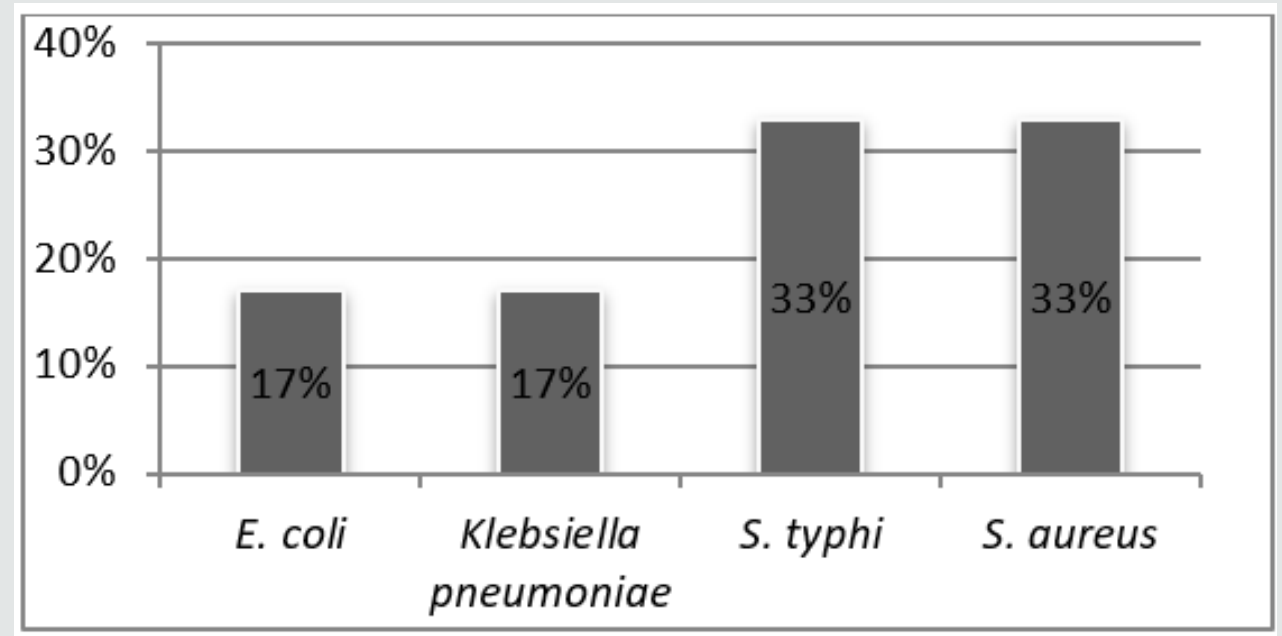

Figure 1: Percentage of obtained organisms in meat samples

Table 1: Cultural Characteristic of isolates detected in meat samples.

\begin{tabular}{|c|c|c|c|}
\hline Sample & Organism & Cultural & Microscopic Examination \\
\hline Minced chicken & E. coli & $\begin{array}{c}\text { On MacConkey, it gives pink pointed colonies while on EMB gives } \\
\text { green metallic sheen }\end{array}$ & $\begin{array}{c}\text { Short thin rods } \\
\text { BSA }\end{array}$ \\
\hline Minced beef & S. typhi & $\begin{array}{c}\text { It gives colorless colonies on SS agar and black color colonies on } \\
\text { Short rods }\end{array}$ & Highly mucoid colonies on MacConkey agar \\
\hline Minced fish & K. pnuemoniae & rods \\
\hline Minced lamb & S. aureus & \begin{tabular}{c} 
Golden yellow colonies of Staphylococcus aureus on Nutrient Agar \\
\hline
\end{tabular} \\
\hline
\end{tabular}




\begin{tabular}{|c|c|c|c|}
\hline Minced mutton & S. typhi & It gives colorless colonies on ss agar and black color colonies on & BSA \\
\hline Minced camel & Staph. aureus & $\begin{array}{c}\text { Golden yellow colonies of Staphylococcus aureus on Nutrient Agar } \\
\text { plate }\end{array}$ & Cocci in bunches \\
\hline
\end{tabular}

Table 2: Antibiotic susceptibility testing.

\begin{tabular}{|c|c|c|c|c|c|c|c|c|c|c|}
\hline Organism & $\begin{array}{l}\text { Streptomycin } \\
\text { (S)300 } \mathrm{\mu g}\end{array}$ & Result & $\begin{array}{l}\text { Sulphamethoxazole } \\
\text { (Spx)10 } \mu \mathrm{g}\end{array}$ & Result & $\begin{array}{l}\text { Oxacillin } \\
(0 x) 1 \mu g\end{array}$ & Result & Tetracycline & Result & Ceftriaxone & Result \\
\hline E. coli & $24 \mathrm{~mm}$ & $S$ & $22 \mathrm{~mm}$ & $S$ & - & - & $22 \mathrm{~mm}$ & S & $21 \mathrm{~mm}$ & $S$ \\
\hline S. typhi & $24 \mathrm{~mm}$ & S & $20 \mathrm{~mm}$ & S & - & - & No zone & $\mathrm{R}$ & $22 \mathrm{~mm}$ & S \\
\hline $\begin{array}{c}\text { K. } \\
\text { pneumoniae }\end{array}$ & $30 \mathrm{~mm}$ & S & $22 \mathrm{~mm}$ & $S$ & - & - & $21 \mathrm{~mm}$ & S & $24 \mathrm{~mm}$ & S \\
\hline S. aureus & $26 \mathrm{~mm}$ & $\mathrm{~S}$ & - & - & No zone & $\mathrm{R}$ & $22 \mathrm{~mm}$ & S & $23 \mathrm{~mm}$ & $\mathrm{~S}$ \\
\hline
\end{tabular}

\section{Result}

In this study, different samples such as beef, fish, mutton, chicken, lamb and camel meat were analyzed which shows that meat sample is contaminated with foodborne pathogens such as E. coli, Staph. aureus, S. typhi, Klebsiella pneumoniae. It was found that 33\% isolates of S. typhi and S. aureus were found whereas $17 \%$ isolates of E. coli and Klebsiella pneumoniae were detected from various meat samples. Most of the isolates were members of the Enterobacteriaceae so they differentiate based on lactose fermenter and nonlactose fermenter. E. coli and Klebsiella gave pink colored colonies on MacConkey agar while S. typhi gave colorless colonies. Biochemical testing was performed to differentiate among Enterobacteriaceae and identification of bacterial species. E. coli gave indole and methyl positive while Voges Proskauer and citrate negative. Klebsiella pneumoniae gave a positive VP test and citrate utilizing test.

In TSI test, acidic slope and acidic butt was found with gas production. S. typhi gave only MR test positive and in TSI it gave alkaline slop, acid butt with $\mathrm{H}_{2} \mathrm{~S}$ production. All presumptively identified cultures were plated onto the selective medium, such as E. coli was inoculated on EMB agar. After incubation, it gives green metallic sheen. S. typhi was streaked on BSA and it gives black centered colonies with a black zone with metallic sheen surrounding the colonies. The positive result of catalase and coagulase test confirms the presence of Staph. aureus. All the identified isolates were susceptible to streptomycin, ceftriaxone, and sulfamethoxazole with average zones of inhibition at the respective concentrations as shown in Table 3 while staph. aureus was found resistant to oxacillin and s. typhi was found resistant to tetracycline.

\section{Discussion}

This study was conducted to investigate the microbial load of foodborne pathogens in different raw meat sample which is available in open retail shops of Karachi. The presence of bacteria in raw meat has been widely reported from different parts of the world [24]. Some reports have recognized the presence of viable bacteria, especially gram-negative organisms from 106 to 109 , as an indication of open-air meat spoilage [51]. In this study we detected the presence of pathogenic bacteria in raw meat including salmonella spp. (33\%), Escherichia coli (17\%), staphylococcus aureus (33\%), and Klebsiella pneumonie (17\%) which reflects the role of animal meat as a major reservoir for spreading pathogenic agents. Therefore, meat handlers and sellers should be made aware of the adverse effects of a lack of proper personal and environmental hygiene, along with sanitation.

Also, consumers should properly wash and cook the to avoid cross-contamination [25]. In this study raw chicken sample was found to be contaminated with E. coli (n=17). The presence of this indicator organism in raw meat might have originated from animal tissues or contaminated tools used during slaughtering and related treatment or cutting process. The identification of $E$. coli in this study showed the presence of fecal contamination and previous studies have shown that the presence of these organisms in food makes food unhealthy for consumption [26]. The high rate of prevalence of $S$. aureus $(\mathrm{n}=33)$ in raw lamb and camel meat indicates the presence of cross-contamination, which is usually related to human skin and clothing. This level of food contamination by this pathogen might lead to the food intoxications. Moreover, it is a major target in the screening of slaughterhouse carcasses to monitor hygienic conditions [27]. Raw beef and mutton sample were found to be contaminated with Salmonella typhi $(\mathrm{n}=33)$. The presence of $S$. typhi in raw meat indicates that the contamination is from human origin and may be the result of poor personal hygiene during the handling and processing of food. Salmonella continues to be a serious threat to consumer health not only due to its pathogenicity but also to its ability in adapting many different environments. The results of this study indicate that the rate of salmonella contamination in retail meat samples were high, ranging from $17 \%$ from beef and mutton samples [28]. In our study Klebsiella pneumonie $(\mathrm{n}=17)$ isolates were detected from the raw fish meat sample. A high incidence of Klebsiella spp from raw meat was also reported previously. Our data confirmed that the sold raw meat is of poor bacteriological quality and poses a high risk for consumer health. All the identified isolates were susceptible to streptomycin, ceftriaxone, and 
sulphamethoxazole antibiotic while $S$. typhi was found resistant against tetracycline. Staph. aureus showed resistance to oxacillin so it can be said that staph. aureus may have the ability to produce beta-lactamases enzyme.

In the developing world, foodborne infection leads to the death of many children, as well as resulting in diarrheal disease which can have long-term effects on children's growth as well as on their physique To reduce the foodborne pathogens, like E. coli, staph. aureus Klebsiella and salmonella contamination rates in retail raw meats, it is critical that risk reduction strategies are used throughout the food chain. These strategies include on-farm practices that reduce pathogen carriage, increased hygiene at both slaughter and meat processing, continued implementation of HACCP systems, and increased consumer education efforts. Additionally, consumption of undercooked meat products and cross-contamination during food handling and preparation must be avoided to ensure food safety at home and in the foodservice industry.

\section{References}

1. Collins Njie Ateba, Thato Setona (2011) Isolation of enteric bacterial pathogens from raw mincemeat in Mafikeng, north-west province, South Africa life science journal 8(s2).

2. http: / / www.sciencedirect.com / science/article/pii/ s0309174012003385.

3. http://www.fao.org/fishery/topic/12318/en.

4. http://www.meritresearchjournals.org/asss/content/2014/march/ antwi-agyei\%20and\%20maalekuu.pdf.

5. http://www.whfoods.com/genpage.php?tname=foodspice\&dbid=117.

6. http://www.iasj.net/iasj?func=fulltext\&aid=55070.

7. Al-sheddy, AN Al-Owaimer, Res Bult (2000) College of food and agricultural sciences, King Saud University 5(98).

8. M Zidane, A Kassem, A Dougbag, E El Ghazali, M Abd el Aziz, et al. (2000) Journal of anatomy.

9. http: / / www.sciencedirect.com/science/article/pii/ s0309174012003385.

10.h t t p : / / w w w.s c i elo.br / s c i elo.ph p ? pi d=s 1516 635x2004000300001\&script=sci_arttext.

11. Olaoye OA, Nilude AA (2010) Investigation on the potential use of biological agents in the extension of fresh beef in Nigeria. World journal of microbiology and biotechnology 26:1445-1454. 12.http:// w w w.s ciencedirect.com/science/article/ pii/016816059601135x.

13. Gram, Dalsgaard (2002) l. gram and p. Dalsgaard, fish spoilage bacteriaproblems and solutions, current opinion in biotechnology 13 (2002) pp. 262-266.

14. Gram, Huss (1996) l gram and h h huss, microbiological spoilage of fish and fish products, international journal of food microbiology 33(1): 121-122.

15. Ayadi A, Culioli J, Abouelkaram S (2007) Sonoelasticity to monitor mechanical changes during rigor and aging. Meat science 76(2): 321326.

16. Bate smith EC (1939) Changes in elasticity of mammalian muscle undergoing rigor mortise. Journal of physiology 96(4): 176-193.

17. Bate smith EC, Bendall JR (1949) Factors determining the time course of rigor mortis. Journal of physiology $110(1)$ : 47-65.

18. http://www.agriculturejournals.cz/publicfiles/28360.pdf.

19. file:///e:/file,871,en.pdf.

20. "food poisoning" at Dorland's medical dictionary.

21. Okonkwo IO, Ukuti OE, Ikpoh IS, Nkang AO, Udezea O, et al. (2010) Assessment of the bacteriological quality of fresh meats sold in Calabar metropolis, Nigeria.

22. Ejeafche 9(1): 89-100.

23. Collinsnjie ateba, Thato setona (2011) Isolation of enteric bacterial pathogens from raw mincemeat in Mafikeng, north-west province, south Africa life science journal 8(s2).

24. Alemseged F, Yami A, Birke WS, Mariam Z, Worku K (2009) Investigation of dysentery outbreak and its causes, Jia city southwest, Ethiopia. Ethiopia journal of health and science 19(3): 147-154.

25. Alhaj NA, Shamsuddin MN, Zamri HF, Abdullah R (2008) Extraction of essential oil from nigella sativa using supercritical carbon dioxide: a study of antibacterial activity. Journal of pharmacological and toxicological 3(4): 225-228.

26. Bokanyi RP Jr, Stephens JF, Foster DN (1990) Isolation and characterization of Salmonella from broiler carcasses or parts. Poult Sci 69: 592-598.

27. Duffy EA, Belk KE, Sofos JN, Ballinger GR Pape A, Smith GC (2001) Extent of microbial contamination in the United States pork retail products. J Food Prot 64: 172-178.

28. Microbial contamination in the United States pork retail products. J Food Prot 64:172-178.

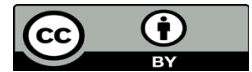

This work is licensed under Creative Commons Attribution 4.0 License

To Submit Your Article Click Here: Submit Article
DOI: $10.32474 / 0 A J C A M .2020 .02 .000141$

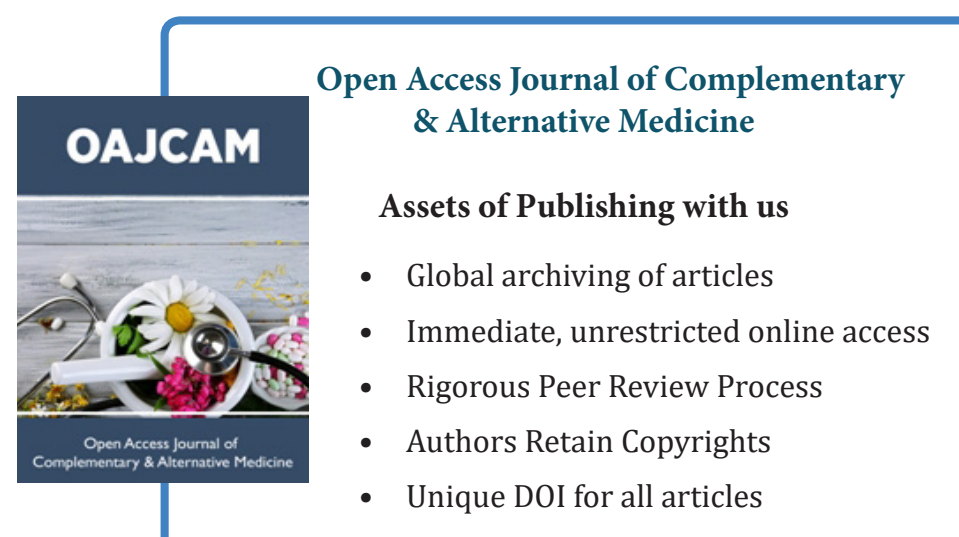

